\section{Social Work}

\section{\& Education}

CSW\&E, 2021

Удк 3.364-3-042.3

DOI: $10.25128 / 2520-6230.21 .3 .2$

\section{Катерина Ігнатенко,}

кандидат педагогічних наук,

доцент кафедри соціальної

роботи,

Луганський

національний

університет імені Тараса

Шевченка,

площа Гоголя, 1, м. Старобільськ,

Луганська обл., Україна, 92300

gulyewa.78@ukr.net

ORCID ID: https://orcid.org/00000002-2853-0340

\section{Cmamyc cmammi:}

Отримано: серпень 01, 2021

1-иеремензувания: вересень 05, 2021

Прийнято: вересень 30, 2021
Ігнатенко, К. (2021). Соціальний захист дітей в діяльності державних організацій на сході України. Social Work and Education, Vol. 8, No. 3. pp. 329-340.

DOI: $10.25128 / 2520-6230.21 .3 .2$

\section{СОЦІАЛЬНИЙ ЗАХИСТ ДІТЕЙ В ДІЯЛЬНОСТІ ДЕРЖАВНИХ ОРГАНІЗАЦІЙ НА СХОДІ УКРАЇНИ}

Анотація. В статті досліджується функції органів місцевого самоврядування в системі соціального захисту дітей. Найбільшим викликом для влади під час збройного конфлікту на сході України $є$ створення надійного середовища для дітей і для тих сімей, які мають складні життєві обставини або опинилися в групі ризику i потребують допомоги. Ризики, які загрожують дітям під час надзвичайних ситуацій, в тому числі у ході збройного конфлікту, залежать від рівня організації й стабільності державної системи соціального захисту та ії спроможності вчасно реагувати на виклики пов'язані 3 надзвичайним станом. Аналіз теоретично-практичного матеріалу, законодавчих актів i звітів неурядових організацій i гуманітарних місій засвідчує, що підтримка європейських стандартів захисту дітей урядом сприяє реформам в Україні. Це обумовлює пошук додаткових ресурсів в громадах та за ïх межами. «Соціальний захист» - це сукупність нормативно закріплених гарантій та дій з боку державних органів влади спрямованих на вирівнювання положення громадян не дивлячись на вік з іншими членами суспільства у випадках настання соціальних, політичних та інших видів ризиків. Подана стисла характеристика нормативно-правової бази, яка обумовлює необхідність соціального захисту дітей, а також перелік державних органів, які відповідають за виявлення дитини, що потребує соціального захисту. Схарактеризовано групи чинників ризику, яким піддаються діти у мирному житті, та які загострюються в екстремальних ситуаціях. Захист дітей у дослідженні представлений у вигляді кіл, які створюють захисне середовище i які порушуються або набувають фрагментарного прояву в надзвичайних ситуаціях. Необхідними умовами соціального захисту $є$ налагодження та розвиток взаємодії й партнерства між органами місцевого самоврядування, виконавчої влади, закладами соціальнопедагогічного спрямування та громадськими організаціями; створення системи соціальних послуг у територіальній громаді, у тому числі для захисту дітей. Особливо це актуально в умовах воєнного конфлікту, який продовжується на сході України.

Ключові слова: соціальний захист; об'єднана територіальна громада (ОТГ); органи місцевого самоврядування; центр соціальних служб; соціальні послуги. 


\section{Вступ}

Регулярні артилерійські обстріли, перестрілки зі стрілецької зброї, поля, засіяні боєприпасами, які можуть вибухнути в будь-який момент, міни, хвороби, нестача їжі, антисанітарні умови для проживання, недостатні запаси вугілля та дров на зиму - з усіма цими проблемами щоденно зіштовхуються дорослі, а разом 3 ними й діти, які мешкають вздовж лінії розмежування на сході України. Актуальність захисту дитинства через підвищений ризик вразливості та дискримінації в діяльності державних органів влади особливо посилюється в умовах кризових ситуацій, зокрема під час збройних конфліктів, що й визначило мету нашої статті.

\section{Аналіз останніх досліджень і публікацій}

На основі ретельного вивчення вітчизняних та зарубіжних публікацій складається досить повне уявлення про сучасний стан проблеми захисту прав дітей та ролі держави в іiі вирішенні. Вивченням різних аспектів захисту дітей, а також змістовної сторони діяльності державних і недержавних організацій в цьому напрямку, займалися такі вчені, як О. Безпалько, В. Бочарова, Л. Волинець, I. Звєрєва, А. Капська, Л. Коваль, Г. Лактіонова, Л. Міщик, А. Мудрик, В. Оржеховська, С. Толстоухова, І. Трубавіна. Треба також відмітити вклад в вивчення цієї теми Ж. Петрочко, яка докладно дослідила світову історію та практику соціально-правового захисту дітей, які опинилися у складних життєвих обставинах. Дослідженню існуючої системи захисту прав дитини на державному, регіональному та місцевому рівнях, а також діяльності міжнародних організацій, які працюють в цій царині присвячені роботи І. Ковчиної, А. Мудрик, А. Зінченко, Ю. Гапон, І. Смолюк. Технології реалізації охоронно-захисної функції фахівця з соціальної роботи на державному, регіональному та місцевому рівнях висвітлені О. Караман, Н. Красновою С. Харченко, Т. Васильковою, О. Холостовою, 3. Кияницею, Л. Пєтушковою, М. Кравченко. Проблеми захисту прав дітей в умовах збройного конфлікту вивчали Л. Волинець, О. Кочемировська та інші дослідники.

Мета дослідження: проаналізувати діяльність деяких державних установ i органів 3 соціального захисту дітей в умовах збройного конфлікту на сході України.

Методологія дослідження складає вивчення та аналіз законодавчої бази, зміни до нормативних документів за останні два роки. Також синтез вже опублікованих напрацювань через пошукові сторінки в інтернеті. Головним підходом в нашому дослідженні було не просто розглянути теоретичні меседжі а й порівняти 3 реальної практикою здійснення соціального захисту на місцях, тобто в населених пунктах, які розташовані в Луганській та Донецькій області. В нас $є$ можливість здійснювати польові візити до так званої контактної лінії лінію розмежування в п’яти кілометровій зоні від розведення війсь у складі міжнародної місії «Центр 3 питань захисту цивільного населення». Також в основу методологічного дослідження теми ліг аналіз звітів ОБСС та інших гуманітарних місій, які працюють на сході України. 


\section{Основна частина}

Концептуальні основи формування та реалізації державної політики України щодо захисту прав дітей виходять з міжнародної Конвенції про права дітей, яка була ратифікована нашою країною ще в 1991 році. Однак, початком діяльності 3 міжнародно-правового регулювання в галузі захисту прав дітей вважається створення у 1923 р. Міжнародного союзу порятунку дітей. У той час права дітей розглядалися в основному в контексті заходів, які необхідно було прийняти відносно рабства, дитячої праці, торгівлі дітьми. Союзом було розроблено перший міжнародний акт - Декларацію прав дитини (або Женевську декларацію), яка поставила питання про заборону примусової дитячої праці. У цілому Женевська декларація складається 3 п'яти основних принципів, які лягли в основу Конвенції про права дитини; історія виникнення якої безпосередньо пов'язана знову ж таки зі світовою кризою, а саме 3 другою світовою війною. Україна, ратифікувавши Конвенцію, гарантувала комплекс основних соціальних прав, які захищають дітей вже 30 років від початку існування незалежності держави. Зобов'язання по виконанню цих прав цих прав, які для міжнародного співтовариства є загальновизнаними, одночасно породжує зобов'язання України як перед кожним індивідуумом, так і перед міжнародною спільнотою.

Цей крок вже автоматично був пов'язаний з удосконаленням вітчизняної системи соціального забезпечення та розробкою нових механізмів соціального захисту дитинства в Україні. Низка законодавчих актів, таких як Конституція України, Сімейний, Кримінальний та Кримінально процесуальний кодекси України, Закони України «Про охорону дитинства», «Про запобігання та протидію домашньому насильству», «Про органи і служби у справах дітей та спеціальні установи для дітей», «Про соціальні послуги», «Про протидію торгівлі людьми» та інші визначають права дітей та обов'язки різних інститутів щодо їх захисту. Здійснюючи захист прав дітей, держава спрямовує свою діяльність на встановлення та забезпечення соціально-економічних i соціально-культурних прав маленьких громадян. Це і право на охорону здоров'я, забезпечення житлом, здобуття освіти, охорону материнства та дитинства, матеріальне забезпечення дітей-сиріт та дітей, позбавлених батьківського піклування, та дітей зі складних життєвих обставин різних категорій тощо. Отож, ми розуміємо під соичіальним захистом сукупність нормативно закріплених гарантій та дій з боку державних органів влади спрямованих на вирівнювання положення громадян не дивлячись на вік з іншими членами суспільства у випадках настання соціальних, політичних та інших видів ризиків. У вузькому сенсі - соціальний захист дітей - це забезпечення державними органами організаційно-правових умов та проведення невідкладних заходів, які спрямовані на створення умов для нормальної життєдіяльності та в інтересах дітей не дивлячись на зовнішні ризики та небезпеку.

В останні роки мають місце певні позитивні тенденції в напрямку реформування системи захисту дітей: законодавче закріплення норм соціального захисту дітей відповідно до міжнародного права; імплементований програмноцільовий підхід до вирішення завдань охорони дитинства; $\epsilon$ спроби удосконалення механізму фінансової підтримки сімей 3 дітьми; розширення 
участі громади й неурядових організацій у подоланні проблем уразливих груп населення тощо. Звичайно, що до ідеального ще $\epsilon$ куди рухатися. Нинішня система захисту прав дітей в Україні має низку обмежень, часто не може розв'язати ключові проблеми, коли дії в інтересах дітей наштовхуються на цілий ряд юридичних колізій та перешкод з боку органів місцевого самоуправління (Міністерство юстиції, 2020 р.). Чи неабиякої уваги потребує посилення соціального захисту дітей від державних органів та організацій на сході України, де вже восьмий рік точиться збройний конфлікт. Отже, згідно з нормами міжнародного і вітчизняного права, має бути особливе заступництво і захист дитини і те, що діти в будь-яких конфліктних та надзвичайних ситуаціях завжди повинні отримувати необхідний захист першими.

Апріорі вже відомо, що небезпека життю дитини особливо загострюється під час гуманітарних катастроф. Безперечним $є$ те, що система захисту прав дітей сягає багатьох закономірних процесів у так званому захисному середовищі дитини. Рівні, або кола захисного середовища мають мультиплікаційні складники, які порушуються або набувають фрагментарного прояву в ситуаціях непередбачуваного та/або глобального характеру під впливом зовнішніх факторів. Система захисту стає уразливою і в результаті страждають інтереси та порушуються права дитини, яка знаходиться в центрі всієї системи. Під час надзвичайних дій завданням державних організацій $є$ визначення тенденцій та закономірностей, викликів та прогалин у системі надання допомоги постраждалому населенню у зоні конфлікту (як на загальнонаціональному, так $\mathrm{i}$ на локальному рівні). Відповідно до сфер життєдіяльності виникають ризики для життя дитини в умовах збройного конфлікту. Вчені виділяють наступні групи чинників ризику, яким піддаються діти у мирному житті, та які загострюються в екстремальних ситуаціях:

- медичні (відсутність/обмеженість доступу до лікування, надання медичних послуг тим, хто має певну групу здоров'я, порушення психічного та фізичного розвитку, погіршуються умови народження дитини тощо);

- соиіально-економічні (складні життєві умови, ускладнення адаптації та, як наслідок, непристосованість до життя у суспільстві - втечі, бродяжництво, неробство, злочини, спроби суїциду, агресивна поведінка, адиктивна поведінка; втрата родини, батьків, як наслідок, отримання статусу дитина-сирота та дитина, позбавлена батьківського піклування умови тощо);

- психологічні (відчуження від соціального середовища, порушення спілкування 3 оточуючими, емоційна нестійкість, дезадаптація, труднощі у взаємодії з ровесниками та дорослими тощо);

- педагогічні (невідповідність умов освітнього закладу, затримка темпу психічного розвитку дітей та темпу навчання, відсутність інтересу до навчання, закритість для позитивного досвіду тощо) (Летунова, 2015, цитоване у Рибакової та Бабиніної, 2015).

Отже, збройний конфлікт, який триває на сході України, може призвести до втрати можливості виховуватись в сім'ях, рости здоровими, здобувати якісну освіту, всебічно й гармонійно розвиватися та бути впевненими у своєму майбутньому. Задля зменшення або уникнення цих ризиків, діти, що перебувають 
на сході Україні, становляться об'єктом діяльності різних структур та інституцій. Зокрема в Законі України «Про запобігання та протидію домашньому насильству» суб'єктами виявлення та/або організації соціального захисту дітей, які перебувають у складних життєвих обставинах, визначені органи державної влади, органи місцевого самоврядування, заклади освіти, охорони здоров'я, соціального захисту населення, інші заклади та установи, зокрема структурні підрозділи районних, районних у мм. Києві та Севастополі держадміністрацій, виконавчих органів міських, районних у містах (у разі утворення) рад, сільських, селищних рад об'єднаних територіальних громад, служби у справах дітей, центри соціальних служб, фахівці із соціальної роботи або інші надавачі соціальних послуг. Також в межах своїх повноважень здійснюють соціальний захист дітей органи Національної поліції, територіальні органи ДСНС та підпорядковані підрозділи, спеціалізовані установи з надання безоплатної первинної правової допомоги, регіональні та місцеві центри 3 надання безоплатної вторинної правової допомоги, бюро правової допомоги, суди, органи прокуратури, уповноважені органи $з$ питань пробації, інші загальні та спеціалізовані служби підтримки осіб, постраждалих від домашнього насильства та насильства за ознакою статі (Закон України «Про забезпечення соціального захисту дітей, які перебувають у складних життєвих обставинах», 2020).

3 метою вдосконалення системи забезпечення прав дітей в Україні, шляхом удосконалення механізмів та процедур прийняття рішень щодо захисту дитини за місцем iі фактичного перебування були створені соціальні служби у справах дітей. Метою їх діяльності $\epsilon$ ефективне вирішення проблем, забезпечення можливості всебічного розвитку, успішної адаптації та соціалізації дітей. 3 точки зору захисту дітей на сході України, завдання служб визначаються проблемами та потребами дітей, розв'язання яких вимагає:

-інтеграції дитини, що має статус переселенця, у загальноосвітньому навчальному закладі;

- формування об’єктивної самооцінки у дітей, які постраждали внаслідок збройного конфлікту; допомога у створенні життєвого плану, здійснення профорієнтації;

-виявлення порушень прав дітей та їх захист щодо отримання необхідних компенсацій, виплат, які гарантовані статусом дитини;

-корекція поведінки дитини, що порушена внаслідок перебування на території де триває збройний конфлікт;

-відвідування дитини вдома і вивчення умов їі життя, виховання і розвитку задля подальшого соціального супроводу або перенаправлення до інших фахівців / за необхідністю;

-створення умов для збереження та укріплення фізичного, психічного, морального, соціального здоров'я дитини;

-формування та розвиток моральних якостей, соціально значимих орієнтацій, життєвих установок;

-попередження та усунення десоціалізуючих впливів мікросоціуму на розвиток дитини; 
-створення сприятливих умов для розвитку пї здібностей, реалізації можливостей;

- надання соціальної, психологічної, педагогічної підтримки та допомоги, впровадження системи профілактичних, реабілітаційних заходів, спрямованих на оптимізацію процесу соціальної адаптації дитини в умовах збройного конфлікту.

Прикладну функцію соціального захисту дітей також виконують заклади соціального обслуговування: соціальні гуртожитки для дітей-сиріт та дітей, позбавлених батьківського піклування, центри соціально-психологічної допомоги, центри матері і дитини, центри для ВІЛ-інфікованих дітей та молоді, центри соціально-психологічної реабілітації дітей і молоді 3 інвалідністю та центри ресоціалізації наркозалежної молоді. I хоча ці заклади в України функціонують не так давно, уже можна впевнено говорити про їх ефективність і реальну допомогу сім'ям та молоді на сході України особливо в 2014-2015 роках.

Дослідження діяльності державних органів в системі соціального захисту та забезпечення дітей і молоді на сході України показало, що немаловажну роль у подоланні наслідки збройного конфлікту «першої хвилі» у 2014-2015 роках відіграли центри соціальних служб для сім’і, дітей та молоді (ЦСССДМ). Ці установи проводять соціальну роботу 3 сім'ями, дітьми та молоддю, що знаходяться в складних життєвих обставинах, здійснюють оцінку їхніх потреб, визначають види соціальних послуг та методи соціальної роботи з ними. Окрім того, що спеціалісти Центрів соціальних служб для сім’ї, дітей та молоді виконували свої повсякденні функції, а саме: раннє виявлення, облік, ведення банку даних та соціальний супровід сімей, які опинилися у складних життєвих обставинах; соціальний патронаж багатодітних сімей, які опинились у складних життєвих обставинах; підготовка до самостійного життя, соціальна адаптація, соціальний супровід дітей-сиріт та дітей, позбавлених батьківського піклування, із числа учнів старших класів та випускників інтернатних закладів; здійснення соціальної роботи, спрямованої на запобігання відмовам від новонароджених дітей, соціальна підтримка вагітних жінок та жінок з новонародженими дітьми; пошук, відбір, навчання та забезпечення соціального супроводження прийомних сімей та дитячих будинків сімейного типу; соціальна підтримка ВІЛ-інфікованих вагітних жінок, дітей, молоді та членів їхніх сімей; соціально-психологічній реабілітація дітей та молоді з інвалідністю; соціально-профілактична робота щодо запобігання правопорушенням та соціальне небезпечним хворобам, подолання їх наслідків у дитячому та молодіжному середовищі, в тому числі серед груп ризику, формування навичок здорового способу життя; надання соціальних послуг та соціальний патронаж неповнолітніх та молоді, які перебувають у місцях позбавлення волі або звільняються 3 них, то із початком збройного конфлікту на сході України додався такий напрямок в діяльності державних соціальних служб як соціальна підтримка дітей, батьки яких вимушені були переселитися 3 непідконтрольної державою території України. Завданнями фахівців з соціальної роботи є соціальний патронаж таких сімей; консультування із соціально-правових питань; сприяння в отриманні пільг, допомоги, компенсацій та інших виплат, матеріальної й натуральної допомоги; консультування 3 питань самозабезпечення; сприяння у вирішенні питань зайнятості, влаштування на 
курси перепідготовки, сприяння інтеграції внутрішньо переміщених осіб у громаду, а також попередження посттравматичних синдромів (Сьомкіна, 2015 р.). Загалом, станом на 2021 рік за даними Міністерства соціальної політики України в Сдиній інформаційній базі даних про внутрішньо переміщених осіб числиться на обліку майже 1 млн. 475 тисяч переселенців 3 тимчасово окупованих територій Донецької та Луганської областей та АР Крим, з них майже 200 тисяч дітей віком до 18 років (дані з офіційного сайту Міністерства соціальної політики України, 2021 p.).

3 наведеного вбачаємо, що здійснення захисту прав дитини для багатьох державних органів є досить складним у мирний час і ще складнішим у період збройного конфлікту. Задля зменшення жертв серед дітей, у Законі України «Про забезпечення прав і свобод внутрішньо переміщених осіб» (2014 р.) удосконалено систему заходів та дій органів держави стосовно дітей-сиріт, дітей, позбавлених батьківського піклування, дітей без супроводження дорослих, а також підтримки сімей $з$ дітьми, зокрема, шляхом визначення, що всі функції щодо захисту прав та інтересів внутрішньо переміщених дітей покладаються на органи опіки та піклування за місцем фактичного перебування дитини. Це дає можливість забезпечити оперативне влаштування дітей-сиріт, дітей, позбавлених батьківського піклування, в патронатні сім’ї та вирішувати інші проблеми дітей i сімей, які віднесені до компетенції органів опіки та піклування.

Зважаючи на ситуацію в країні, соціальному захисту як певному процесу притаманні зміни, які спрямовані на покращення становища дітей, що мешкають в усіх куточках країни. Проаналізував результативність цих змін для дітей, що мешкають на сході України, ми зробили такі висновки: 32014 року в Україні відбувається реформа децентралізації влади, що трансформує місцеве самоврядування, в тому числі й систему соціального захисту. Відповідно до розпоряджень Кабінету Міністрів, в Україні сформовано 1469 територіальних громад, які покриватимуть усю територію країни. Згідно з Законом України «Про добровільне об'єднання територіальних громад» спроможний базовий рівень місцевого самоврядування формується за рахунок створення об'єднаних територіальних громад, до складу яких ввійшли місцеві ради. Система соціальних послуг за реформою сьогодні має наблизитися до людей. Якщо подивитися на соціальний захист в діяльності державних органів широко, то його можна поділити умовно на дві категорії: 1) адміністративні послуги - субсидії, надання матеріальної допомоги чи виплат; 2) догляд та супровід тих, хто не може це зробити самостійно. Раніше соціальний захист покладався на служби у справах дітей, Управління соціального захисту, Центри соціальних служб для сім’ї дітей та молоді, територіальні центри надання соціальних послуг. Саме захист дітей нині набирає більше сили через те, що законодавець дає можливість обирати громадам самостійно надавача таких послуг - чи то центр соціальних служб, чи то профільна громадська або благодійна організація, чи то фізична особа підприємець. Для захисту дітей кожна громада створює свої служби у справах дітей, або їх підрозділи, що повинно впливати на кількість виявлення в громаді дітей-сиріт та дітей, позбавлених батьківського піклування та на їх виявлення. В 
деяких громадах задля захисту дітей та їх соціального забезпечення створюються Центри надання соціальної підтримки для дітей та сімей.

Треба відмітити й той факт, що на сході України не у всіх населених пунктах сформувалися громади, у 18 територіальних громадах Донецької та Луганської областей не відбулись місцеві вибори, в них за наказом Президента України від 19.02.2021№61/2021 та 62/2021 органом міського самоуправління на міському, селищному і сільському рівнях $є$ військово-цивільні адміністрації (далі - ВЦА), на початок 2021 року їх нараховується 19, в Донецькій області - 11, в Луганській - 8. В Законі Україні «Про військово-цивільні адміністрації» зазначається, що військово-цивільні адміністрації утворюються як тимчасовий вимушений захід 3 елементами військової організації управління для забезпечення безпеки та нормалізації життєдіяльності населення в районі відсічі збройної агресії Російської Федерації, зокрема в районі проведення антитерористичної операції, що не має на меті зміни та/або скасування конституційно закріпленого права територіальних громад на місцеве самоврядування. Отже це означає, що держава не знімає з себе зобов'язань по збереженню прав мешканців Сходу України - дітям, які мешкають на лінії розмежування, у так званій «сірій зоні», майже щодня наражаючи своє життя на небезпеку, вкрай необхідний соціальний захист в громаді. Створення структурних підрозділів /відділів соціального захисту населення при ВЦА $є$ необхідним для забезпечення і захисту прав й основоположних свобод громадян України. Їх формування відбувається згідно з Законом України «Про соціальні послуги», підзаконних актів 3 питань організації та діяльності органів місцевого самоврядування $з$ питань соціального захисту населення, враховуючи методичні рекомендації 3 розроблення положень про структурні підрозділи 3 питань соціального захисту населення державних адміністрацій. Завданнями державних організацій $є$ забезпечення реалізації на території громади державної політики у сфері соціального захисту населення, формування місцевих програм соціальної підтримки, надання соціальних послуг особам, окремим соціальним групам, які перебувають у складних життєвих обставинах i не можуть самостійно їх подолати. Функції соціальних установ різноманітні, але чи не найголовніша - це організація відповідно до законодавства здійснення соціальної роботи в громаді, в тому числі виявлення осіб, сімей, які перебувають у складних життєвих обставинах. В межах цієї функції відділ соціального захисту може приймати рішення про організацію надання соціальних послуг, у тому числі шляхом соціального замовлення, державних закупівель, державно - приватного партнерства, проведення конкурсу соціальних проектів тощо.

Зараз в деяких громадах ще до сих пір $є$ актуальними питання фінансування сфери соціального захисту громад, де передбачені бюджетом виплати різним категоріям. А майже чи не в кожній ОТГ або ВЦА, на жаль, питання придбання житла дітям-сиротам залишається недофінансованим або зовсім ця лінійка в бюджеті залишається пустою. Також вкрай малими залишаються витрати на програми реабілітації й компенсації дітям-війни, тим дітям, що постраждали внаслідок воєнних дій та збройних конфліктів визначення згідно з 1 статтею Закону України «Про охорону дитинства». 


\section{Висновки}

На державу покладено обов'язок вживати всіх необхідних заходів для забезпечення захисту дітей, які перебувають у зоні воєнних дій i збройних конфліктів, дітей, які постраждали внаслідок воєнних дій і збройних конфліктів, догляду за ними та возз'єднання їх із членами сім'ї, включаючи розшук, звільнення з полону, повернення в Україну дітей, незаконно вивезених за кордон (стаття 30/1 Закону України «Про охорону дитинства»). Усі дії держави стосовно захисту дітей, які перебувають у зоні воєнних дій і збройних конфліктів, дітей, які постраждали внаслідок воєнних дій i збройних конфліктів, здійснюються відповідно до норм міжнародного гуманітарного права.

Соціальний захист дітей на сході України зараз перебуває у стадії трансформації. Тому дуже важливо в процесі реформи не загубити дитину, тобто максимально врахувати інтереси уразливих категорій, в тому числі дітей-сиріт та дітей, позбавлених батьківського піклування. Згідно з вимогами законодавства, процес визначення потреб у соціальних послугах мають організовувати i здійснювати відповідні підрозділи соціального захисту органів місцевого самоврядування та органів виконавчої влади. Фахівець із соціальної роботи, звичайно, є одним із головних суб'єктів цієї роботи на закріпленій за ним дільниці чи у громаді.

Основне завдання фахівця соціальної сфери - допомогти членам сім’і усвідомити наявність проблеми та допомогти їм самим знайти варіанти іï вирішення, визначити, що вони можуть зробити самостійно і яка саме за таких умов їм необхідна допомога від спеціалістів, держави. Державні органи місцевого самоврядування з усією відповідальністю ставляться до розвитку превентивних соціальних послуг для сімей і дітей, надання допомоги на ранніх етапах вразливості, особливо у зоні конфлікту. Головною метою діяльності центрів/відділів соціального захисту, які уповноважені брати участь у реалізації державної політики шляхом проведення соціальної роботи, є поліпшення або відновлення якості життєдіяльності, захист конституційних прав, свобод i законних інтересів, задоволення культурних та духовних потреб сімей, дітей та молоді.

Отже, враховуючи різноманітність підходів до розуміння сутності процесу соціального захисту та спираючись на дослідження провідних фахівців у цій сфері, можна зробити висновок, що соціальний захист дітей в діяльності державних органів повинен бути спрямований на мінімізацію негативного впливу збройного конфлікту, здійснення соціального виховання, надання різних видів соціальної допомоги й підтримки, налагодження взаємовідносин із соціальним оточенням, адаптацію поведінки й психоемоційного стану дітей, що мешкають на сході України, де на сьогоднішній день продовжується війна.

\section{Література}

Візир, В.\& Чернета, С. (2017). Соціальний захист дітей. Регіональна стратегія. Дніпропетровська область. Отримано з URL: https://decentralization.gov.ua/pics/upload/22768182ec10b5b3ca08326d5756636df66.pdf .

Ігнатенко, К. (2020). Органи місцевого самоврядування як суб'єкт системи соціального захисту дітей у територіальній громаді. Науковий вісник 
Південноукраӥнського національного педагогічного університету імені К. Уиинського, випуск 3 (132), Одеса, 41-47.

Кияниця, 3.,\& Петрочко, Ж. (Ред.). (2017). Соціальна робота із вразливими сім'ями $i$ дітьми. В 2-х ч.; Ч. І. Сучасні орієнтири та ключові технологї. К. : ОБНОВА КОМПАНІ.

Про забезпечення організаційно-правових умов соціального захисту дітей-сиріт та дітей, позбавлених батьківського піклування, №2342-IV (2020). URL: https: rada.gov.ua )

Про забезпечення соціального захисту дітей, які перебувають у складних життєвих обставинах, №585 (2020). URL: https://zakon.rada.gov.ua/laws/show/585-2020-\%D0\%BF

Про місцеве самоврядування в Україні, №280/97-BP (1997). URL: https: rada.gov.ua )

Про соціальні послуги, №2671-VIII (2019) URL: http://zakon0.rada.gov.ua/laws/show/966-15

Рыбакова, Л. А., Бабынина, Т. Ф. (2015). Дети группь риска: особенности развития, психологопедагогические технологии работы с детьми группы риска. Казань: Издательство «Бриг».

Слозанська, Г. (2017). Чому варто спиратися на теорії соціальної роботи під час планування інтервенцій у практиці соціальної роботи в територіальній громаді: критичний аналіз. Збірник наукових прац̧ь «Педагогічні науки», №78 том 2, 204-209. 


\section{THE SOCIAL PROTECTION OF CHILDREN IN THE ACTIVITIES OF THE GOVERNMENT ORGANIZATIONS IN EAST OF UKRAINE}

Kateryna Ihnatenko, Ph.D. in Pedagogy, Associate Professor, Senior Lecturer at the Department of Social Work, Luhansk Taras Shevchenko National University, Ukraine; gulyewa.78@ukr.net

Abstract. The article examines the organization of local governments in the system of social protection of children in communities. The biggest challenge for the authorities, during an armed conflict is to create a safe environment for children and for those families who have lives in situation and need social assistance The risks that threaten children during emergencies also depend on different factors, for example, external protection factors, including the level of organization and stability of the state social protection system and its ability to respond promptly to the allocations required by the state of emergency. As shown by the analysis of theoretical and practical material, legislation, and reports on non-governmental organizations and humanitarian missions, the government supports European standards of child protection, which contribute to reforms in Ukraine. The leads to the search for additional resources in communities and beyond. The author defines the concept of «social protection» as a set of statutory guarantees and actions by public authorities aimed at equalizing the situation of citizens regardless of age with other members of society in cases of social, political and other risks. A brief description of the legal framework, which determines the need for social protection of children, as well as a list of government agencies responsible for identifying a child in need of social protection. The author characterizes the groups of risk factors to which children are exposed in a peaceful life, and which are exacerbated in extreme situations. The protection of children in the study is presented in the form of circles that create a protective environment and which are violated or become fragmentary in emergencies. Necessary conditions for the social protection are the establishment and development of interaction and partnership between local governments, the executive branch, socio-pedagogical institutions and public organizations; creation of a system of social services in the territorial community, including for the protection of children. This is especially true in the context of the ongoing the military conflict in Eastern Ukraine, when threats increase tenfold and resources, unfortunately, are limited.

Keywords: social protection; united territorial community; local government organization; social service; center of social services. 


\section{References}

Ihnatenko, K. (2020). The Local Governments as a Subject of the Child Protection System in the Local Community. Scientific Bulletin of the Ukrainian National Pedagogical University named $K$. Ushinsky, 3 (132), 41-47. [in Ukrainian].

Kyyanytsya \& Petrochko, (2017). Social work with the vulnerable families and children. The modern landmarks and key technologies: manual at 2 part. P. 1. - K.: OBNOVA KOMPANI, 2017. - 256 p. [in Ukrainian].

Resolution of the cabinet of Ministers of Ukraine «On ensuring social protection of children in difficult life circumstances». Retrieved from On ensuring social protection... $\mid$ from 01.06.2020 No 585 (rada.gov.ua) [in Ukrainian].

Rybakova, L. \& Babynina, T. (2015). The children at the group of risk: the features of development, psychological and pedagogical technologies for working with the children at the risk. Kazan: Brig Publishing House, 200 p. [in Russian].

Slozanska, H. (2017). Why it is necessary to rely on the theory of social work when planning interventions in the practice of social work in the local community: a critical analysis. Collection of scientific works «Pedagogical sciences», 78 (2), 204-209. [in Ukrainian].

Vizyr, V, Cherneta, S. (2017). Social protection of children. Regional strategy. Dnipropetrovsk region. Retrieved from https://decentralization.gov.ua/pics/upload/22768182ec10b5b3ca08326d5756636df66.pdf [in Ukrainian].

The Low of Ukraine «About maintenance of organizational and legal conditions of social protection of orphans and children deprived of parental care». Retrieved from https://zakon.rada.gov.ua/laws/show/2342-15\#Text [in Ukrainian].

The Low of Ukraine «About local self-government in Ukraine» Retrieved from https://zakon.rada.gov.ua/laws/main/280/97-\%D0\%B2\%D1\%80\#Text [in Ukrainian].

The Law of Ukraine «On Social Services». Retrieved from http://zakon0.rada.gov.ua/laws/show/966-15 [in Ukrainian].

Article history:

Received: August 01, 2021

1st Revision: September 05, 2021

Accepted: September 30, 2021 